\title{
Ashmore and Cartier Islands
}

National Cancer Institute

\section{Source}

National Cancer Institute. Ashmore and Cartier Islands. NCI Thesaurus. Code C123741.

Islands in the Indian Ocean, located midway between northwestern Australia and T imor island. 